\title{
Daya Tarik Wisata Unggulan Di Daerah Transit Kota Pematangsiantar, Sumatera Utara
}

Christiani Situmorang a, 1, Ida Bagus Suryawan a, 2

${ }^{1}$ christiani_nuena@yahoo.com, 2idabagussuryawan@unud.ac.id

a Program Studi S1 Destinasi Pariwisata, Fakultas Pariwisata,Universitas Udayana, Jl. Dr. R. Goris, Denpasar, Bali 80232 Indonesia

\section{Abstract}

Research on the travel attractions featured in transit area Pematangsiantar, North Sumatra, intend to find an activity that is do by tourist in transit and to know the attraction featured of travel attraction for transit tourist. Data collection techniques in this study, by observation, in-depth interviews with the actors of tourism in Pematangsiantar, and literature study by means of documentation using a variety of documents, such as books and literature. Documentation can also be done by taking a picture in Pematangsiantar. The data obtained were analyzed by using qualitative descriptive analysis of the data that describes, depicts, and systematic explanation of the data obtained in the field with the aim of obtaining a clear and objective.

This research is located in Pematangsiantar, North Sumatra. The results of this research is to be able to make Pematangsiantar as transit areas must be identified ahead of the tourist attraction featured for transit travelers. To determine the leading tourist appeal, it is necessary to know the behavior patterns of travelers in transit while in Pematangsiantar, starting from what place you visit, what you buy, and how long the stay. Of traveler behavior patterns, it can be concluded that the appeal is the leading tourist tourist attraction most visited by tourists in transit and has many tourist activities, are: culinary tourism, cultural tourism, nature tourism and religious tourism.

Keywords: Tourist Attraction Featured, Transit Area

\section{PENDAHULUAN}

Pariwisata merupakan sektor penting dalam upaya penerimaan Pendapatan Asli Daerah yang cukup potensial. Pariwisata adalah segala sesuatu yang berhubungan dengan wisata dan daya tarik wisata serta usaha yang terkait dengan bidang tersebut. Berbicara tentang pariwisata di dalamnya tercakup berbagai upaya pemberdayaan, usaha pariwisata, objek dan daya tarik wisata serta berbagai kegiatan dan jenis usaha pariwisata.

Smith (1989, dalam Wardiyanta, 2006) menyatakan bahwa secara substansi pariwisata merupakan bagian dari budaya suatu masyarakat, yaitu berkaitan dengan cara penggunaan waktu senggang yang dimiliki seseorang. Sebenarnya, pariwisata dapat dilihat dari berbagai sudut pandang karena kekompleksitasannya, misalnya pariwisata sebagai pengalaman dari seseorang, pariwisata sebagai perilaku sosial, pariwisata sebagai bisnis, dan pariwisata sebagai fenomena geografik.

Pariwisata memiliki beragam bentuk dan jenis, seperti pariwisata alam, budaya, konvensi, belanja, dan pariwisata minat khusus. Pariwisata telah menjadi industri yang mampu mendatangkan devisa negara dan penerimaan asli daerah yang berimplikasi pada kesejahteraan masyarakat dalam berbagai sektor ekonomi. Kota Pematangsiantar merupakan salah satu kota di Provinsi Sumatera Utara, dan kota terbesar kedua di Provinsi Sumatera Utara setelah Kota Medan. Bandar udara yang ada di Sumatera Utara memiliki nama Bandara Internasional Kualanamu yang diresmikan operasionalnya pada tanggal 27 Maret 2014 oleh mantan Presiden Republik Indonesia Susilo Bambang Yudhoyono.

Bandara ini merupakan bandara terbesar kedua di Indonesia setelah Bandar Udara Intenasional Soekarno-Hatta. Lokasi bandara ini terletak di Deli Serdang, Sumatera Utara, tepatnya $39 \mathrm{~km}$ dari Kota Medan. Bandara baru ini dibangun untuk menggantikan Bandar Udara Internasional Polonia yang telah beroperasi lebih dari 85 tahun. Perpindahan Bandara Kualanamu membuat jarak yang ditempuh dari Kota Pematangsiantar tidak terlalu jauh, karena dapat sampai lebih cepat dari waktu untuk pergi ke Bandara Polonia sebelumnya.

Kota Pematangsiantar memiliki berbagai potensi alam, budaya, dan sejarah yang dapat digali serta dilestarikan untuk menjadi asset dalam mendukung pengembangan sektor kepariwisataan. Kota Pematangsiantar terdiri dari \pm 15 etnis dan ras antara lain Batak simalungun, Toba, Karo, Tapsel (Tapanuli selatan), Tapteng (Tapanuli tengah), Jawa, Nias, Minangkabau, Tionghoa, Melayu, Aceh, Pakpak, India, Makassar. Masing - masing etnis memiliki 
karakter yang ramah dan saling mendukung satu sama lain. Tiap etnis memiliki budaya dan kesenian daerah yang berbeda-beda dan merupakan potensi pengembangan kepariwisataan.

Kota Pematangsiantar terletak ditengahtengah wilayah Kabupaten Simalungun yang merupakan perlintasan dari wilayah tapanuli menuju kota medan dan dari wilayah timur menuju wilayah barat, oleh karena itu kota Pematangsiantar telah ditetapkan sebagai daerah transit oleh pemerintah setempat, baik diluar kegiatan pariwisata maupun kegiatan pariwisata untuk menuju ke sebuah destinasi dan salah satu contoh menuju ke Danau Toba (salah satu destinasi yang terkenal di Sumatera Utara).

Upaya Pemerintah dalam membangun pariwisata di Sumatera Utara dapat dilihat dalam fenomena yang baru terjadi di tahun ini, dimana Presiden Jokowi berupaya untuk membangun pariwisata di Sumatera Utara, khususnya pariwisata Danau Toba. Dapat terlihat dari keputusan kepala negara yang menetapkan Danau Toba sebagai pusat perayaan HUT Kemerdekaan RI ke-71 pada 17 Agustus 2016 sebelumnya. Acara kenegaraan tersebut akan digelar di danau vulkanis terbesar di dunia, selain itu akan digelar kegiatan Karnaval Katulistiwa atau sering disebut dengan Pesta Rakyat. Kegiatan tersebut diselenggarakan dalam rangka mempromosikan pariwisata Danau Toba ke seluruh dunia serta memperingati perayaan HUT RI ke-71. Rangkaian acara tersebut juga banyak diikuti oleh 26 provinsi, 7 kabupaten di sekitar Toba, 8 sub-etnik, dan berbagai komunitas budaya.

Selain kegiatan baru yang telah terlaksana pada tahun ini, Sumatera utara juga memiliki kegiatan yang diperingati setiap tahunnya dan dirayakan secara besar - besaran oleh sebagian besar masyarakat Sumatera Utara. Kegiatan tersebut biasa dikenal dengan nama Pesta Danau Toba. Sejarah Pesta Danau Toba dimulai sejak tahun 1980, kegiatan ini dilaksanakan karena merupakan wujud syukur suku Batak terhadap anugerah Danau Toba yang berperan utuh terhadap kehidupan suku Batak yang bermukim disekitar danau tersebut. Pada awalnya kegiatan ini hanya sebatas event lokal, namun seiring berjalannya waktu kegiatan ini mulai dilirik oleh pemerintah provinsi dan telah berganti nama menjadi Festival Danau Toba yang bertujuan untuk melestarikan kebudayaan dan warisan leluhur. Festival Danau Toba telah melibatkan banyak pihak dalam pelaksanaannya baik masyarakat Sumatera Utara maupun masyarakat yang berada diluar Sumatera Utara.

Diadakannya kegiatan ini, dapat menjadikan salah satu motivasi bagi wisatawan untuk mengunjungi Sumatera Utara, khususnya transit di Kota Pematangsiantar. Jumlah wisatawan yang mengunjungi Danau Toba biasanya akan cenderung mempengaruhi jumlah kunjungan wisatawan transit di Kota Pematangsiantar. Hal ini dapat terjadi karena jarak dan waktu yang cukup panjang sehingga membuat wisatawan terhenti sejenak dan dapat beristirahat dalam beberapa jam. Berbagai aktivitas banyak dilakukan oleh wisatawan, baik itu wisatawan domestik maupun wisatawan mancanegara yang sedang berada di Kota Pematangsiantar, kebanyakan wisatawan yang hanya transit untuk menuju ke sebuah destinasi yang ada di Sumatera Utara, kerap hanya tinggal dalam beberapa jam di Kota Pematangsiantar serta sedikit melakukan aktivitas pariwisata.

Menurut Leiper (1990), dalam Cooper, dkk (1999), elemen-elemen dari sebuah sistem pariwisata yang sederhana menyangkut sebuah daerah/negara asal wisatawan (Traveler generating region), sebuah daerah/negara tujuan wisata (Tourist destination region), dan sebuah tempat transit (Transit route region). Dalam keterangan tempat transit dinyatakan bahwa bukan saja mewakili waktu dan tempat sementara dalam sebuah perjalanan wisata untuk mencapai daerah tujuan wisata utama, tetapi juga menyangkut kesempatan untuk menjadi tujuan wisata.

Berdasarkan keterangan model sistem pariwisata diatas sangat tertarik untuk meneliti fenomena ini dan ingin mengetahui daya tarik wisata unggulan yang tepat untuk dikembangkan di kota ini sesuai dengan keinginan dari wisatawan transit serta kesiapan dari masyarakat lokal, dan mempunyai tujuan untuk membuat Kota Pematangsiantar ini dikenal oleh wisatawan, serta dapat menghasilkan produk wisata baru yang diinginkan oleh wisatawan dan dapat membuat wisatawan tinggal dalam beberapa hari di kota ini untuk menikmati daya tarik wisata yang ada 
di kota Pematangsiantar bahkan dapat menjadikan kota Pematangsiantar sebagai daerah tujuan wisata yang memang layak dikunjungi oleh wisatawan.

\section{TINJAUAN PUSTAKA}

Penelitian ini menggunakan studi terdahulu dari beberapa akademisi/peneliti yang membahas mengenai wisata transit, baik secara langsung maupun tidak langsung. Akademisi yang dimaksud antara lain Hodamc Clymont and Bruce Priedaux (2007) yang mendeskripsikan Trip Behaviour wisatawan seperti rencana perjalanan, karakteristik wisatawan, preferensi objek wisata, dan aktivitas wisatawan. Hasil penelitian mereka menunjukkan bahwa untuk menarik wisatawan ke Goodwindi diperlukan identikasi karakterisitik dan aktifvitas wisatawan termasuk promosi yang intensif, namun demikian perlu diperhatikan pula peran kerjasama diantara stakeholders (pemerintah, pihak swasta, dan masyarakat setempat untuk mengemangkan pariwisata di GoodWindi.

Adapun konsep dan teori yang digunakan adalah sebagai berikut:

\section{Konsep Tentang Daya Tarik wisata}

Menurut Undang-Undang Republik Indonesia Nomor 10 Tahun 2009 tentang Kepariwisataan pada pasal 1 ayat 5 menyatakan bahwa: Daya Tarik Wisata adalah segala sesuatu yang memiliki keunikan, keindahan, dan nilai yang berupa keanekaragaman kekayaan alam, budaya, dan hasil buatan manusia yang menjadi sasaran dan tujuan kunjungan wisatawan. Oleh karena itu, daya tarik wisata harus dikelola sedemikian rupa agar keberlangsungan dan kesinambungannya terjamin.

Menurut Cooper, dkk (1995) dalam Ismayanti, (2010), terdapat empat (4) komponen yang harus dimiliki suatu daya tarik wisata, yaitu :

a) Atraksi (attraction) dapat dibagi menjadi dua macam, yakni :

- Natural Resources (alami), seperti : Gunung, Danau, Pantai, dan Bukit.

- Attraction Feature (buatan), seperti :Culture (Museum, galeri seni, sirkus arkeologi), Traditions (cerita rakyat, ritual keagamaan, festival), Event (sport activities dan event budaya).

b) Fasilitas (aminities)
Secara umum pengertian aminities adalah segala macam sarana dan prasarana yang diperlukan oleh wisatawan selama berada di DTW. Sarana dan prasarana yang dimaksud seperti: Penginapan (accommodation), Rumah Makan (restaurant), Transportasi dan Agen Perjalanan.

c) Aksesbilitas (accessibility)

Sesuatu yang memberikan kemudahan untuk menghubungkan wisatawan dari negara daerah asal ke negara daerah tujuan selama berada di destinasi wisata tersebut. Jalan masuk atau pintu utama ke suatu destinasi wisata merupakan akses penting dalam kegiatan pariwisata yakni infrastruktur, seperti : Bandar udara, pelabuhan kapal, terminal bus dan taxi, stasiun kereta api dan jalan. Transportasi seperti : udara, laut, darat (pesawat, kapal pesiar, bus pariwisata, kereta api dan taxi).

d) Pelayanan Tambahan (ancillary service)

Ancillary services yaitu organisasi kepariwisataan yang dibutuhkan untuk pelayanan wisatawan seperti destination marketing management organization conventional dan visitor bureau.

Yang dimaksud daya tarik wisata dalam penelitian ini merupakan elemenelemen yang terkandung dalam destinasi dan lingkungan di dalamnya yang secara individual atau kombinasinya memegang peran penting dalam memotivasi wisatawan untuk berkunjung ke destinasi tersebut. Daya tarik wisata yang ada biasanya dapat berupa daya tarik wisata alam, sejarah, kuliner, dan religi. Adapun daya tarik wisata unggulan di daerah transit, yang dimaksud dalam penelitian ini adalah daya tarik wisata yang banyak diminati oleh wisatawan transit, kemudian dari seluruh aktivitas wisata yang berlangsung dapat diurutkan menjadi wisata unggulan sesuai dengan tingkatan yang paling banyak dikunjungi.

\section{Konsep Tentang Tipologi Wisatawan}

Pariwisata ada karena adanya wisatawan, sehingga kajian terhadap wisatawan merupakan salah satu fokus dalam dunia pariwisata. Teori Cohen (dalam Pitana 2005), menekankan pada tingkah laku wisatawan. Cohen mengembangkan tipologi wisatawan pada 4 klasifikasi, sebagai berikut: 
a. Organized - Mass Tourist

Wisatawan yang sanggup melakukan perjalanannya bila menggunakan jasa pengaturan perjalanan wisata. Jenis wisatawan ini tidak berbeda jauh dnegan jenis wisatawan masal, karena mereka berkunjung secara rombongan yang tidak terpisahkan, sekecil mungkin menghindari atraksi yang menantang, memperhatikan faktor kenyamanan, keamanan, dan selalu dipandu oleh pemandu wisata, serta menuntut fasilitas yang mirip dengan tempat tinggalnya.

b. Individual Mass Tourist

Wisatawan masal atau rombongan dengan mengunjungi destinasi yang sudah banyak dikunjungi wisatawan pada umumnya. Jenis wisatawan seperti ini banyak dijumpai di suatu kawasan destinasi yang dapat menampung serta melakukan aktivitas wisata dalam jumlah yang banyak, misalnya kawasan Danau Toba, Parapat yang terbentang luas, dimana wisatawan sering melakukan kegiatan yang sifatnya senang - senang, foto-foto, dan berenang, serta aktivitas pariwisata lainnya.

c. Explorer

Wisatawan mengatur perjalanan sendiri, mengikuti jalan yang tidak umum, menginginkan interaksi dengan komunitas lokas, serta memanfaatkan fasilitas yang disediakan oleh komunitas local, karakter seperti ini biasanya dimiliki oleh wisatawan yang memiliki jiwa petualang, selalu memperhatikan atraksi yang sifatnya masih alami, unik, dan memiliki nilai historis serta budaya. Wisatawan jenis ini sering disebut sebagai wisatawan yang berkualitas karena selain menjaga lingkungan dan budaya yang ada, mereka juga terkadang melakukan penelitian.

d. Drifter

Wisatawan yang ingin mengunjungi destinasi dimana mereka belum mengetahui tentang kondisi destinasi sebelumnya. Pada dasarnya seseorang melakukan kegiatan wisata melalui tahap perencanaan yang meliputi pencarian informasi tentang kondisi destinasi. Jenis wisatawan ini pada umumnya mengunjungi destinasi transit atau ampiran sebagai kegiatan untuk melakukan eksplorasi.

Dalam penelitian ini, yang dimaksud dengan tipologi wisatawan adalah mengklasifikasikan wisatawan atas dasar tingkat familiarisasi dari daerah yang akan dikunjungi serta tingkat pengorganisasian dari perjalanan wisata. Tipologi wisatawan juga didasarkan pada kebutuhan riil, yaitu faktor demografis dan sosial ekonomi, seperti: Usia, Status marital, Gender, dan Mata pencaharian.

\section{Konsep Tentang Daerah Transit}

Tidak seluruh wisatawan harus berhenti di daerah transit. Namun, seluruh wisatawan pasti akan melalui daerah tersebut sehingga peranan daerah transit pun penting. Rute Transit (Transit Route) adalah tempat sementara dalam sebuah perjalanan wisata untuk mencapai daerah tujuan wisata utama, tetapi mempunyai kesempatan untuk menjadi daerah tujuan wisata (enroute tourism destination). Dalam konsep ini selalu ada interval waktu dan tempat dalam sebuah perjalanan wisata ketika seorang wisatawan merasa mereka telah meninggalkan tempat asalnya tetapi belum sampai di tempat yang mereka pilih untuk dikunjungi sebagai daerah tujuan wisata.

Jadi, dalam konsep daerah transit ingin bertujuan membuat wisatawan untuk tinggal sementara waktu sebelum sampai pada destinasi utama dan dapat menghabiskan sebagian uangnya di daerah transit yaitu Kota Pematangsiantar serta dapat menjadikan Kota ini sebagai destinasi pariwisata. Seringkali terjadi, perjalanan wisata yang berakhir di daerah transit, bukan di daerah tujuan. Hal inilah yang membuat negara - negara seperti Singapura dan Hong Kong berupaya menjadikan daerah multifungsi, yakni sebagai daerah transit dan daerah tujuan wisata.

\section{Teori Leiper}

Menurut Leiper (1990), dalam Cooper, dkk (1998), elemen-elemen dari sebuah sistem pariwisata yang sederhana 
menyangkut sebuah daerah/negara asal wisatawan, sebuah daerah/negara tujuan wisata, dan sebuah tempat transit. Terlihat lima elemen pokok, yaitu travelergenerating region, departing traveler, transit route region, tourist-destination region, dan returning traveler. Namun inti dari kelima elemen tersebut menyangkut tiga hal pokok, yaitu elemen wisatawan, tiga elemen geografis (gabungan dari travel generator, transit route, dan tourist destination) dan elemen industri pariwisata.

\section{Elemen Wisatawan}

Wisatawan adalah aktor dari sistem pariwisata. Pariwisata, pada akhirnya adalah sebuah pengalaman yang berisi humanis, menyenangkan, dan tidak terlupakan serta menjadi salah satu bagian pengalaman terpenting dari hidup pelakunya.

2. Elemen Geografis

Menyangkut tiga elemen, yaitu : (1) traveler-generating region, (2) tourist destination region, dan (3) transit route region. Traveler - generating region merupakan asal dan pasar pariwisata di mana calon wisatawan mencari informasi tentang tujuan wisatanya, melakukan transaksi pemesanan (booking) perjalanan wisata, dan dari mana wisatawan tersebut berangkat menuju tempat tujuan wisata.

Tourist destination region merupakan tujuan perjalanan wisata. Sebagai daerah tujuan wisata, dampak pariwisata akan terasa paling besar dari daerah lainnya. Biasanya tujuan wisata merupakan daerah dengan keunikan tersendiri yang berbeda dengan daerah lain, termasuk daerah atau negara asal wisatawan. Keunikan dan perbedaan tersebut bisa berupa budaya, sejarah, alam, dan sebagainya. Keunikan ini biasanya disebut daya tarik wisata. Hal inilah yang menjadi energi utama bagi keseluruhan sistem pariwisata, yang mengakibatkan permintaan akan perjalanan wisata bagi traveler generating region. Pada daerah tujuan wisata inilah konsekuensi yang paling dramatis dari sistem pariwisata terjadi.
Transit route region bukan saja mewakili waktu dan tempat sementara dalam sebuah perjalanan wisata untuk mencapai daerah tujuan wisata utama, tetapi juga menyangkut kesempatannya untuk menjadi tujuan wisata antara (enroute tourism destination). Dalam konsep ini selalu ada interval waktu dan tempat dalam sebuah perjalanan wisata ketika seorang wisatawan merasa mereka telah meninggalkan tempat asalnya tetapi belum sampai di tempat yang mereka pilih untuk dikunjungi sebagai daerah tujuan wisata.

3. Elemen Industri Pariwisata

Elemen terakhir dalam model Leiper adalah industri pariwisata yang dapat kita bayangkan sebagai wilayah bisnis dan organisasi yang terlibat dalam menghasilkan produk pariwisata. Sebagai contoh, travel agents dan tour operators adalah yang utama ditemukan dalam kategori traveller-generating region. Atraksi wisata dan industi perhotelan/restoran ditemukan di destination region. Sektor transportasi umumnya ditemukan di transit route region.

\section{METODE PENELITIAN}

Sumber data yang dipergunakan dalam penelitian ini adalah:

a) Data Primer, informasi yang bersumber dari pengamatan langsung ke lokasi penelitian, hasil wawancara dan diskusi dengan pihak pemerintah (Kepala Dinas Kebudayaan dan Pariwisata Kota Pematangsiantar), masyarakat lokal baik yang bekerja di industri pariwisata, serta beberapa wisatawan transit yang sedang berkunjung.

b) Data Sekunder, data yang sudah terkumpul sebelumnya seperti jumlah kunjungan Wisatawan, monografi Kota Pematangsiantar, dan artikel lain yang berkaitan dengan penelitian ini.

Metode pengumpulan data yang digunakan dalam penelitian ini adalah: 
1. Observasi

Pengumpulan data dengan cara pengamatan langsung untuk mendapatkan gambaran yang jelas tentang kondisi eksisting Kota Pematangsiantar, untuk mengetahui potensi yang dimiliki Kota Pematangsiantar. Observasi ini disertai dengan mencermati dan mencatat menggunakan alat bantu observasi. Catatan yang merekam hasil observasi dapat berupa rekaman percakapan dan dokumentasi foto pada saat di daerah penelitian.

\section{Wawancara}

Pengumpulan data dengan melakukan Tanya jawab secara langsung dengan informan yang bersangkutan, baik dengan pedoman pertanyaan yang telah disusun sebelumnya maupun dapat muncul dari suatu percakapan bebas, guna memperoleh keterangan dan informasi yang lebih mendalam. Responden dalam hal ini adalah Kepala Dinas Kebudayaan dan Pariwisata Kota Pematangsiantar, tokoh masyarakat dan wisatawan yang sesuai dengan kriteria yaitu wisatawan transit.

\section{Studi Kepustakaan}

Dalam upaya pengumpulan data untuk penelitian ini dengan cara studi kepustakaan/dokumentasi menggunakan berbagai macam dokumen seperti buku atau literatur, artikel, karya tulis, peraturan-peraturan, hasil penelitian sebelumnya maupun informasi tertulis yang masih berhubungan dengan penelitian ini.

Teknik analisis data yang dipergunakan dalam penelitian ini adalah analisis deskriptif kualitatif yang merupakan gambaran dari data yang disusun sistematis, aktual dan akurat mengenai fakta - fakta yang ada (Moleong, 1997). Penelitian inii menggunakan metode analisis data secara deskriptif kualitatif yaitu dengan memberikan ulasan dan interpretasi terhadap data yang diperoleh sehingga menjadi lebih jelas. Data yang muncul dalam analisis ini lebih banyak berupa deskripsi tentang gambaran umum Kota Pematangsiantar, deskripsi perilaku wisatawan transit, dan kemudian mendeskripsikan daya tarik wisata unggulan di daerah transit, dan data lain yang menjawab permasalahan yang diangkat. Data dapat diperoleh melalui wawancara mendalam, dengan tujuan memperoleh gambaran yang jelas dan objektif.

\section{HASIL DAN PEMBAHASAN}

Kota Pematangsiantar memiliki berbagai potensi alam, budaya, dan sejarah yang dapat digali serta dilestarikan untuk menjadi asset dalam mendukung pengembangan sektor kepariwisataan. Kota Pematangsiantar terdiri dari \pm 15 etnis, antara lain Batak simalungun, Toba, Karo, Tapsel (Tapanuli selatan), Tapteng (Tapanuli tengah), Jawa, Nias, Minangkabau, Tionghoa, Melayu, Aceh, Pakpak, India, Makassar. Secara geografi Kota Pematangsiantar diapit Kabupaten Simalungun yang memiliki kekayaan perkebunan karet, sawit, teh, dan pertanian. Kemudian kota ini juga menghubungkan jalan darat ke kabupatenkabupaten lainnya, seperti Toba Samosir, Tapanuli Utara, dan Tapanuli Selatan. Sehingga, posisinya sangat strategis sebagai kota transit perdagangan antar kabupaten maupun sebagai daerah transit sebelum menuju ke daerah tujuan wisata yakni, Danau Toba yang terletak di Parapat.

\subsection{Tipologi Wisatawan Transit Di Kota Pematang Siantar}

Menurut hasil observasi di lapangan, banyak wisatawan yang datang ke Kota Pematang Siantar, dan menjadi salah satu daerah yang dikunjungi oleh wisatawan yang berpergian ke Sumatera Utara, baik itu tujuan langsung ke Kota Pematang Siantar maupun hanya transit untuk mengunjungi destinasi wisata yang akan dituju.

Perilaku kunjungan wisatawan merupakan sesuatu yang bersifat dinamis untuk dapat melihat tipologi wisatawan transit yang berada di Kota Pematangsiantar

Perilaku kunjungan wisatawan dapat diamati dari kegiatan yang dilakukan oleh wisatawan, dapat kita lihat dari cara wisatawan itu memilih produk dan jasa 
yang digunakan, dan tentunya dari keinginan wisatawan itu sendiri. Sesuai hasil observasi yang didapat di lapangan, perilaku kunjungan wisatawan transit di Kota Pematang Siantar sesuai dengan tipologi wisatawan. Berdasarkan pengamatan, tipologi wisatawan di Kota Pematang Siantar terdiri dari tiga yaitu : backpacker, travel agent, dan individu Backpacker,

Berdasarkan pandangan Cohen (1972), dalam Pitana (2009), tentang tipologi wisatawan mendapatkan maknan bahwa tipologi backpacker merupakan wisatawan explorer yang melakukan perjalanan dengan mengatur perjalanannya sendiri, mencari hal yang tidak umum serta bersedia memanfaatkan fasilitas standart lokal dengan interaksi yang intensif dengan masyarakat setempat (kerabat).

Wisatawan backpacker biasanya melakukan perjalanan yang cukup jauh dari satu kota ke kota lain, backpacker kerap sekali melakukan perjalanan menggunakan tas bawaan seperti ransel dan terlihat santai dengan barang bawaannya.

Kedua, Travel Agent. Menurut Cohen (1972) tipologi wisatawan ini merupakan wisatawan yang menyerahkan pengaturan perjalanannya kepada agen perjalanan dan mengujungi daerah tujuan wisata yang terkenal. Menariknya, agen perjalanan yang menawarkan paket wisata berada diluar dari Kota Pematang Siantar. Agen perjalanan tersebut diantaranya berasal dari Kota Medan, Padang, dan Riau.

Banyaknya jasa travel agent sangat memudahkan wisatawan yang ingin melakukan perjalanan wisatawan. Biasanya tipe wisatawan yang menggunakan jasa travel agent adalah wisatawan yang tidak mau ambil pusing dalam melakukan perjalanan, seperti contohnya ketetapan harga sudah termasuk dengan biaya transportasi, makan, dan akomodasi. Dari penjelasan diatas, kebanyakan wisatawan yang menggunakan jasa travel agent dalam kumpulan banyak orang/Grouping. Banyaknya wisatawan domestik dalam sebuah kelompok/Grouping yang mengunjungi Pematang Siantar untuk transit berasal dari Medan, Riau, dan Padang.

Tingkat kunjungan wisatawan tertinggi terjadi pada bulan Juni - Januari, hal ini terjadi karena adanya musim liburan untuk anak sekolah dan perguruan tinggi, selain itu ada hal utama yang membuat jumlah kunjungan meningkat di bulan yang sudah ditentukan karena memperingati acara besar di Sumatera Utara yaitu Festival Danau Toba yang diperingati setiap tahunnya pada tanggal 19 - 22 November dan pada bulan ini jumlah kunjungan wisatawan akan meningkat drastis.

Tipologi individu ini berbeda dari yang lain karena memiliki motivasi yang berbeda dalam perjalanan wisatanya. Keberagaman individu yang ada dapat dilihat dari tujuan perjalanannya. Tipologi wisatawan seperti ini yang mengunjungi Kota Pematang Siantar memiliki beberapa tujuan perjalanan, seperti perjalanan bisnis, perjalanan wisata yang disertai dengan aktivitas bisnis dan pertemuan (conference) seluruh SKPD (Satuan Kerja Perangkat Daerah) provinsi Sumatera Utara khususnya dalam acara Festival Danau Toba.

Wisatawan tipologi ini biasanya melakukan perjalanannya yang telah dibuat oleh pihak Dinas atau perusahaan tempat wisatawan ini bekerja. Biasanya untuk kategori wisatawan ini tidak hanya singgah dalam beberapa jam, namun kerap sekali menginap sekitar satu atau dua hari untuk melaksanakan rapat di Siantar dan kemudian menuju ke destinasi utama di Parapat untuk tujuan bekerja atau memenuhi undangan dalam kegiatan yang sudah cukup terkenal yaitu Festival Danau Toba. Waktu yang dimiliki cukup banyak dalam kategori wisatawan transit ini, 2 - 3 hari adalah waktu yang cukup untuk menikmati beberapa objek wisata yang dimiliki Kota Pematang Siantar.

Aktivitas wisata yang dilakukan oleh wisatawan perjalanan dinas ini, lebih mengacu pada alam karena waktu yang dimiliki cukup banyak. Pada siang hari biasanya mereka akan pergi ke beberapa objek wisata yang ada di Siantar, salah 
satunya adalah Air Terjun Bah Biak, Permandian Alam Aek Manik, Kebun Teh Sidamanik, dan Patung Dewi Kwan Im. Perjalanan ke tempat ini tidak terlalu jauh, karena biasa ditempuh paling cepat dalam 10 menit dan paling lama dalam waktu 35 menit. Aksesbilitas yang dimiliki objek wisata ini sudah layak untuk dikunjungi oleh beberapa kendaraan, seperti mobil dan kendaraan sepeda motor. Akomodasi yang digunakan dalam perjalanan dinas menggunakan mobil yang dikendarai oleh seorang supir. Maka dari itu, tidak sulit bagi orang yang melakukan perjalanan dinas untuk mengunjungi objek wisata yang ada di Pematang Siantar maupun sekitarnya, karena transportasi yang digunakan bersifat pribadi dan dapat menyesuaikan sesuai keinginan.

\subsection{Daya Tarik Wisata Unggulan Di Kota Pematang Siantar}

Kota Pematang Siantar memiliki potensi wisata yang cukup potensial, mulai dari daya tarik wisata alam, budaya, buatan, dan peninggalan sejarah. Potensi ini sangat berarti sejalan dengan keberadaan Pematang Siantar. Walaupun keberadaannya bukan sebagai daerah tujuan wisata melainkan sebagai daerah transit yang cukup strategis. Pengembangan dan pembangunan pariwisata di daerah ini telah dilakukan dari tahun ke tahun sebagai upaya untuk meningkatkan daya tarik bagi wisatawan yang sedang transit, yang pada akhirnya dapat menarik minat wisatawan untuk mengunjungi daerah Pematang Siantar sebagai daerah tujuan wisata. Dalam menentukan daya tarik wisata unggulan di daerah ini, peneliti akan mengurutkan aktivitas wisata menurut tipologi wisatawan yang ada di Pematang Siantar, dimana urutan yang paling banyak dikunjungi menjadi urutan pertama, kedua, dan seterusnya sesuai dengan hasil pengamatan maupun wawancara, seperti yang akan dijelaskan dibawah ini :

1) Wisata Kuliner

Wisata kuliner bukanlah hal yang baru dalam dunia pariwisata, menurut Bondan Winarno (2008) industri kuliner di Indonesia memiliki potensi yang cukup besar untuk dikembangkan menjadi destinasi wisata bagi para wisatawan mancanegara maupun domestik karena keberagaman makanan dan minuman khas yang dimiliki setiap daerah. Di Pematang Siantar sendiri, ditunjang oleh kebiasaan masyarakat Batak dan Tionghoa yang menyukai kuliner dan mempunyai cita rasa yang tinggi dalam sebuah kuliner.

Wisata kuliner menjadi pilihan pertama yang paling banyak diminati oleh wisatawan transit. sesuai hasil pengamatan maupun wawancara dengan informan/wisatawan yang memilih wisata kuliner sebagai aktivitas yang banyak dilakukan di Kota Pematang Siantar. Dalam kategori wisata kuliner ini, peneliti menggabungkan wisata kuliner dengan wisata belanja, kegiatan belanja yang dilakukan masih dalam konteks membeli cinderamata (oleh-oleh) yang berupa kuliner.

2) Wisata Budaya

Pariwisata untuk Kebudayaan (Culture Tourism) merupakan jenis wisata yang dirancang untuk mengetahui adat istiadat, gaya hidup, dan kebiasaan hidup masyarakat. Hal ini ditandai dengan adanya rangkaian motivasi, serta keinginan untuk belajar di pusat-pusat pengajaran dan riset, mempelajari monument bersejarah, peninggalan peradaban masa lalu, pusat-pusat kesenian, atau ikut serta dalam festival-festival seni music, teater dan tarian rakyat lainnya.

Wisata budaya menjadi pilihan kedua yang aktivitasnya banyak diminati oleh wisatawan transit. sesuai hasil pengamatan serta wawancara yang dilakukan oleh seluruh informan/wisatawan yang sedang transit memilih wisata budaya sebagai aktivitas yang banyak dilakukan di Kota Pematang Siantar. Daerah Pematang Siantar merupakan salah satu kota yang memiliki catatan sejarah yang menarik, tidak banyak yang mengetahui akan sejarah pada jaman dahulu dimana pada awalnya Pematangsiantar merupakan daerah kerajaan, kemudian Belanda memasuki daerah Sumatera Utara dan daerah Simalungun menjadi daerah kekuasaan belanda sehingga sekitar tahun 1907 berakhirlah kekuasaan raja - raja pada tahun tersebut. Kota Pematang 
Siantar masih memiliki beberapa peninggalan sejarah dan masih dijaga sampai saat ini antara lain Tugu Raja Siantar, Museum Simalungun, Gedung Juang 45.

Dari peningalan sejarah yang sudah disebutkan sebelumnya, tidak banyak wisatawan transit yang mengunjungi tempat diatas melainkan mengunjungi tempat lain dan menggunakan transportasi yang masih masuk dalam kategori wisata sejarah. Hal ini dapat terjadi karena faktor waktu yang begitu singkat untuk wisatawan berkunjung ke tempat - tempat bersejarah diatas. Sebagian besar wisatawan yang banyak melakukan aktivitas dalam wisata sejarah berdasarkan tipologi wisatawan adalah backpacker dan travel agent

3) Wisata Alam

Wisata alam adalah kegiatan perjalanan yang memanfaatkan keindahan alam, baik yang masih alami atau yang sudah ada usaha budidaya, agar memiliki daya tarik wisata di tempat tersebut. Wisata alam biasanya memiliki cukup banyak peminat, baik terhadap wisatawan mancanegara maupun wisatawan domestik. Adapun wisata alam yang dimiliki oleh Pematang Siantar, salah satunya adalah Kebun Teh Sidamanik, Air Terjun Bah Biak, serta Permandian Alam Aek Manik. Untuk lokasi ketiga wisata alam ini, memang tidak langsung berada di sekitaran pusat Kota Pematang Siantar. Membutuhkan waktu \pm 10 menit untuk sampai ke tempat yang paling dekat dan \pm 35 menit ke tempat yang paling jauh.

Wisata alam menjadi pilihan ketiga setelah diurutkan menurut aktivitas yang sering dilakukan oleh wisatawan yang sedang transit. berdasarkan hasil pengamatan serta wawancara mendalam dengan seluruh informan/wisatawan yang sedang transit memilih wisata alam sebagai aktivitas yang banyak dilakukan di Kota Pematang Siantar. Wisatawan yang banyak melakukan aktivitas dalam wisata alam, berdasarkan tipologi wisatawan adalah wisatawan individual. Banyaknya waktu yang dimiliki oleh tipe wisatawan ini membuat sebagian kecil wisatawan yang transit dapat menikmati wisata alam yang ada di sekitaran Pematang Siantar.

\section{SIMPULAN DAN SARAN}

Hasil identifikasi dan analisis dapat disimpulkan untuk dapat menjadikan Kota Pematangsiantar sebagai daerah transit yang unggul maka perlu dikembangkan daya tarik wisata unggulan yang banyak diminati oleh wisatawan transit, dapat dilihat dari pola perilaku wisatawan dan dapat disimpulkan sebagai daya tarik wisata unggulan, yaitu sebagai berikut :

1. Tipologi wisatawan transit dapat dilihat dari perilaku kunjungan wisatawan yang sedang transit di Kota Pematangsiantar kegiatan yang dilakukan oleh wisatawan yang telah dikelompokkan menjadi 3 tipologi, yakni meliputi tipologi wisatawan backpacker, wisatawan tipologi ini banyak melakukan aktivitas dalam kegiatan wisata sejarah dan menikmati wisata kuliner. yang kedua dalam tipologi travel agent/Grouping, wisatawan dalam tipologi ini melakukan aktivitas dalam kegiatan wisata sejarah, wisata religi, dan menikmati wisata kuliner, yang ketiga adalah tipologi wisatawan individual, dimana tipologi wisatawan ini memilih wisata alam dan wisata kuliner menjadi aktivitas yang dilakukan saat sedang transit di Kota Pematang Siantar.

2. Kota Pematang Siantar memiliki potensi wisata yang cukup potensial, mulai dari daya tarik wisata alam, budaya, buatan, dan peninggalan sejarah. Dalam menentukan daya tarik wisata unggulan di Kota Pematangsiantar, sesuai dengan hasil identifikasi dan hasil pengamatan yang menjadi daya tarik wisata unggulan akan diurutkan sesuai dengan ativitas wisata yang banyak dilakukan oleh wisatawan yang sedang transit, kemudian akan diurutkan dari yang paling banyak memiliki aktivitas wisata akan menjadi unggulan. Dimana yang menjadi daya tarik wisata unggulan adalah wisata kuliner, yang kedua adalah wisata budaya, ketiga wisata 
alam dan yang keempat adalah wisata religi.

\subsection{Saran}

Saran yang dapat diberikan penulis kepada pihak Pemerintah adalah, agar memaksimalkan peranan pemerintah untuk mewujudkan Kota Pematang Siantar sebagai Destinasi wisata transit melalui optimalisasi potensi dan daya tarik wisata unggulan yang ada, guna untuk menarik minat wisatawan transit dan dapat membuat Kota Pematang Siantar lebih dikenal oleh wisatawan.

Saran yang dapat diberikan penulis kepada pihak pengelola wisata yang ada di Pematang Siantar, agar merawat dan melestarikan potensi yang sudah ada. Tidak lupa juga untuk tetap memaksimalkan promosi sebaik mungkin dengan bekerja sama dengan pihak pemerintah.

Saran yang dapat saya berikan untuk masyarakat lokal adalah dengan memberikan dukungan melalui keikutsertaannya untuk menjadi masyarakat sadar wisata, sehingga Kota Pematang Siantar dapat terwujud menjadi destinasi wisata transit unggulan di Sumatera Utara.

Saran yang dapat penulis berikan dibidang akademis agar adanya penelitian lanjutan dari penelitian mengenai wisata transit di Pematang Siantar, karena masih banyak terdapat fenomena dan permasalahan yang belum dikaji dalam laporan ini.

\section{Daftar Pustaka:}

Anonim, Undang-Undang No. 10 Tahun 2009 Tentang Kepariwisataan

Cooper et al. 1999. Tourism Principles and Practice. England: Longman

Ismayanti. 2010. Pengantar Pariwisata. Jakarta : Grasindo

Moleong, Lexy. J. 1997. "Metodologi Penelitian Kualitatif". Bandung : Remaja Rosda Karya.

Notoatmodjo, Soekidjo. 2003. Pengembangan Sumber Daya Manusia. Jakarta: Rineka Cipta

Pendit, Nyoman S. 1999. Ilmu Pariwisata Sebuah Pengantar Perdana. Jakarta: PT. Pradnya Paramita

Pitana, I Gede. 2009. Pengantar Ilmu Pariwisata. Yogyakarta: Penerbit Andi

Polhaupessy, Leonard F. et.al. 2006. Perilaku Manusia (Pengantar Singkat Tentang Psikologi). Bandung: PT. Revika Aditama.

Spillane, James. 2005. Ekonomi Pariwisata, Sejarah dan Prospeknya. Yogyakarta: Kanisius.
Wardiyanta, M. 2006.Metode Penelitian Pariwisata. Yogyakarta: ANDI.

Yoeti, Oka A. 1993. Pengantar Ilmu Pariwisata. Bandung: Angkasa

Yoeti, Oka A. Edisi Revisi 1996, Pengantar Ilmu Pariwisata. Bandung: Angkasa

Mcclymont,Hoda. 2007. Drive Tourist: Who Are They Do and How Do Attract Them.

Asean Journal on Hospitality and Tourism. Volume 6, 